\title{
Evidence for functional arterio-venous anastomoses in the ovaries of sheep
}

\author{
P. E. Mattner, B. W. Brown and J. R. S. Hales \\ C.S.I.R.O., Division of Animal Production, P.O. Box 239, Blacktown, New South Wales 2148, \\ Australia
}

\begin{abstract}
Summary. Vessels with histological features characteristic of arterio-venous anastomoses were found in the stroma but not in CL. In 5 conscious ewes at the mid-luteal stage of the oestrous cycle, ovarian blood flow was significantly greater $(P$ $<0.025)$ with microspheres of 50 than of $15 \mu \mathrm{m}$ diameter in ovaries without $\mathrm{CL}$ $(0.23 \pm 0.04$ (s.e.m.) and $0.11 \pm 0.02 \mathrm{ml} / \mathrm{min}$, respectively), but not in ovaries with CL $(4.42 \pm 0.86$ and $3.73 \pm 0.70 \mathrm{ml} / \mathrm{min}$, respectively). In 5 similar but anaesthetized ewes, the portion of each ovarian artery within the ovarian vascular pedicle was bypassed with re-entrant catheters through which microspheres were perfused. A greater proportion $(P<0.01)$ of 50 than of $15 \mu \mathrm{m}$ microspheres was retained in ovaries with (90 and $79 \%$ ) or without ( 82 and $45 \%$ ) a CL.

It is concluded that functional arterio-venous anastomoses are present in sheep ovaries.
\end{abstract}

\section{Introduction}

Histological studies have indicated that arterio-venous anastomoses are present in the ovaries of deer and dogs (Watzka, 1936), rabbits (Dabelow, 1939) and women (Danesino, 1948; Clara, 1956). Nevertheless, controversy exists as to whether such anastomoses are important in the regulation and distribution of the blood supply within the ovary.

In ewes, estimates of ovarian venous outflow (Mattner \& Thorburn, 1969) were much greater than estimates of ovarian capillary blood flow obtained using rubidium chloride, iodoantipyrine or microspheres as tracers (Mattner, Hales \& Brown, 1972; Brown, Hales \& Mattner, 1974; Setchell \& Linzell, 1974). Furthermore, in sheep (Baird, Giles \& Cockburn, 1973) and in women (Fraser, Baird \& Cockburn, 1973), the oxygen partial pressure and content differ only slightly in ovarian arterial and venous blood. While these findings provide circumstantial evidence to suggest that a significant proportion of the ovarian arterial supply may bypass the ovarian capillary beds in some species at least, results with perfusions of $15 \mu \mathrm{m}$ diameter microspheres into ovarian arteries via the abdominal aorta in rabbits (Ahrén, Janson \& Selstam, 1974) indicated that relatively little of the blood bypassed the ovarian capillary beds. The finding that vessels resembling anastomoses were present in the ovarian vascular pedicle in ewes (Lee \& O'Shea, 1976) raised the possibility that if any arterio-venous shunting of ovarian arterial blood occurs in this species, it may take place within the vascular pedicle rather than in the ovary itself.

In the present study, ovaries from ewes were examined histologically for the presence of arterio-venous anastomoses and ovarian blood flow was studied with microspheres of 15 and 50 $\mu \mathrm{m}$ diameter. Because the diameter of capillaries rarely exceeds $8 \mu \mathrm{m}$ and that for patent 
anastomoses falls between 25 and $150 \mu \mathrm{m}$ (Hales, 1974), entrapment of microspheres in organs (and derived blood flow rates) should be greater with $50 \mu \mathrm{m}$ microspheres if functional anastomoses are present.

\section{Materials and Methods}

\section{Animals}

A total of 12 mature Merino ewes at Day 8-10 of the oestrous cycle was used. Oestrus (Day 0 ) was detected by using vasectomized rams.

\section{Histological studies}

The ovaries were removed from 2 ewes immediately after slaughter, fixed in $10 \%$ neutral buffered formalin and embedded in paraffin wax. Serial sections $7 \mu \mathrm{m}$ thick were cut and stained with aldehyde fuchsin (Gomori, 1950), haematoxylin and a modification of Halmi's fast green counterstain (Fullmer, 1959) to aid in the identification of anastomoses (Molyneux, 1965).

\section{Microspheres}

Microspheres of $15 \pm 3.0$ (mean \pm s.d.) $\mu$ m diameter labelled with ${ }^{113} \mathrm{Sn}$ or ${ }^{95} \mathrm{Nb}(\mathrm{New}$ England Nuclear Co., Boston, Massachusetts, U.S.A.) and of $50 \pm 10 \mu \mathrm{m}$ diameter labelled with ${ }^{141} \mathrm{Ce}$ or ${ }^{85} \mathrm{Sr}$ (3M Company, St Paul, Minnesota, U.S.A.) were used. For Exp. 1, doses were prepared as described by Hales (1974). For Exp. 2, doses of microspheres of each size were prepared in catheters $(4 \mathrm{~cm}$ long; i.d. $1.0 \mathrm{~mm}$, o.d. $1.5 \mathrm{~mm}$, filled with saline $(9 \mathrm{~g} \mathrm{NaCl} / \mathrm{l})$. The radioactivity of each dose was determined by using an autogamma spectrometer (Packard Instruments, Model 5320, La Grange, Illinois, U.S.A.: ${ }^{113} \mathrm{Sn}, 355-445 \mathrm{keV} ;{ }^{95} \mathrm{Nb}, 640-830 \mathrm{keV}$; $\left.{ }^{141} \mathrm{Ce}, 60-160 \mathrm{keV} ;{ }^{85} \mathrm{Sr}, 450-560 \mathrm{keV}\right)$.

\section{Experiment 1: ovarian blood flow rates}

In 5 conscious ewes, the rate of ovarian blood flow was assessed by the microsphere method described by Hales (1974) and Brown et al. (1974). In each ewe, known numbers of $15 \mu \mathrm{m}$ microspheres $\left(12-14 \times 10^{6}\right)$ and $50 \mu \mathrm{m}$ microspheres $\left(3-5 \times 10^{6}\right)$ were injected through an indwelling catheter into the left ventricle. A few minutes later, the ewes were killed with an overdose of pentobarbitone sodium given intravenously and the ovaries were removed and examined for corpora lutea. The amount of radioactivity for each isotope in the ovaries was determined with an autogamma spectrometer. During the administration of the microspheres, a sample of blood was withdrawn at about $25 \mathrm{ml} / \mathrm{min}$ from both the left femoral and the right carotid arteries to provide 'reference organ' blood flow and to confirm that both sizes of microspheres were uniformly distributed in the arterial blood.

\section{Experiment 2: perfusion of microspheres into ovarian arteries}

To determine whether functional arterio-venous anastomoses are present in the ovary itself, any shunting of ovarian arterial blood in the ovarian vascular pedicle region was eliminated by the use of bypass catheters in 5 anaesthetized ewes. Anaesthesia was induced with thiopentone sodium and maintained with halothane and oxygen. The genital tract of each ewe was exposed via a mid-ventral abdominal incision. Each ovarian artery was freed from associated structures and cleared of connective tissue over a $2 \mathrm{~cm}$ length at 2 sites, one immediately adjacent to the hilus of the ovary, the other midway between the origin of the artery and the vascular pedicle. A 
dose of 10000 i.u. heparin was then administered intravenously. At each prepared site on each artery, the tapered end of a saline-filled $(9 \mathrm{~g} \mathrm{NaCl} / \mathrm{l})$ expanded catheter $12 \mathrm{~cm}$ long (minor i.d. $0.5 \mathrm{~mm}$, o.d. $1.0 \mathrm{~mm}$; major i.d. $1.0 \mathrm{~mm}$, o.d. $1.8 \mathrm{~mm}$ : Dural Plastics and Engineering, Dural, New South Wales, Australia) was inserted into the lumen of the artery through a small puncture wound and was held in place with fine ligatures. The ovarian arterial supply was interrupted for only 2-3 min and was re-established by attaching the free end of each catheter to a 16-gauge stainless-steel $\mathrm{T}$-piece, the side arm of which was closed. The rate at which perfusions could be made via the side arm of the $T$-piece without retrograde flow occurring in the catheter system was determined for each preparation by infusing a solution of Evans' blue in plasma at various rates. Since infusions of saline at rates which induced retrograde flow (Evans' blue/serum) produced an obvious blood/saline interface within the catheter system, Evans' blue was not used as a marker during perfusions of microspheres.

Subsequently each ovary was perfused with a known number of $15 \mu \mathrm{m}$ diameter microspheres $\left(4.8 \times 10^{3}-5.2 \times 10^{3}\right)$ and, 6-7 min later, with a known number of $50 \mu \mathrm{m}$ diameter microspheres $\left(1.0 \times 10^{3}-1.2 \times 10^{3}\right)$. The $4 \mathrm{~cm}$ long catheter containing the dose was attached to the side arm of the $\mathrm{T}$-piece and the contents were flushed into the bypass catheter with $2 \mathrm{ml}$ saline $(9 \mathrm{~g} \mathrm{NaCl} / \mathrm{l})$ delivered at $0.4 \mathrm{ml} / \mathrm{min}$ from a hand-held syringe. The microspheres were kept dispersed by treatment with ultrasound and care was taken to avoid the introduction of air bubbles. The doses of microspheres and the saline were previously warmed to $39^{\circ} \mathrm{C}$. At this perfusion rate, no visible retrograde displacement of the blood in the catheter system by saline occurred in any of the preparations. Immediately after this procedure, the ovaries were excised and the amount of radioactivity of each isotope used was determined in the same autogamma spectrometer in which the radioactivity of the microsphere doses had previously been determined. Residual radioactivity in the dose catheters, the arterial catheters and the $\mathrm{T}$-piece was also counted in the same instrument so that the numbers of microspheres effectively delivered to each ovary and the proportions retained in the ovaries could be determined.

\section{Analysis of data}

Data obtained for the 15 and $50 \mu \mathrm{m}$ diameter microspheres were analysed by Student's paired $t$ tests.

\section{Results}

\section{Histological examinations}

In each of the 4 ovaries, a small number of vessels with histological features characteristic of arterio-venous anastomoses (Molyneux, 1965) were found in the ovarian stroma, mainly near the region of the hilus; none was found in the corpora lutea (CL). These vessels were usually coiled and could be differentiated from arteries by the absence of an internal elastic lamina and the presence of numerous epithelioid cells within the smooth muscle layer (see Plate 1). The epithelioid cells were distinguished from smooth muscle cells by their unstained cytoplasm and positive aldehyde-fuchsin staining of the intercellular material and/or the cell membrane complex (Molyneux, 1965).

\section{Experiment 1: ovarian blood flow rates}

The microspheres of 15 or $50 \mu \mathrm{m}$ diameter were uniformly distributed in the arterial blood. With each size of microsphere, the numbers per $\mathrm{ml}$ blood in the 'reference' samples withdrawn from the carotid and femoral arteries were highly correlated $(r>0.996, P<0.001)$. The mean 
( \pm s.e.m.) numbers of microspheres of $15 \mu \mathrm{m}$ diameter retained in the ovary with or without a $\mathrm{CL}$ were $20380 \pm 2530$ and $1088 \pm 315$, respectively; the corresponding values for microspheres of $50 \mu \mathrm{m}$ diameter were $6210 \pm 741$ and $542 \pm 105$, respectively.

In each ovary, the blood flow value obtained with $50 \mu \mathrm{m}$ microspheres was greater than that obtained with $15 \mu \mathrm{m}$ microspheres (Table 1 ). While the difference in values was statistically significant only in ovaries without CL $(P<0.025)$, it was of greater magnitude in the contralateral ovaries with $C L$, the mean difference being 0.13 and $0.69 \mathrm{ml} / \mathrm{min}$, respectively.

Table 1. Comparison of estimates of ovarian blood flow $(\mathrm{ml} / \mathrm{min})$ obtained with microspheres of 15 and $50 \mu \mathrm{m}$ diameter used simultaneously in 5 conscious

ewes

\begin{tabular}{cccccc}
\hline & \multicolumn{2}{c}{ Ovary without $\mathrm{CL}$} & & \multicolumn{2}{c}{ Ovary with CL } \\
\cline { 2 - 3 } \cline { 5 - 6 } & $15 \mu \mathrm{m}$ & $50 \mu \mathrm{m}$ & & $15 \mu \mathrm{m}$ & $50 \mu \mathrm{m}$ \\
\hline & 0.10 & 0.14 & & 4.96 & 5.26 \\
& 0.12 & 0.30 & & 3.41 & 3.63 \\
& 0.13 & 0.28 & & 5.52 & 6.73 \\
& 0.14 & 0.32 & & 3.22 & 4.87 \\
& 0.04 & 0.12 & & $1.54 \dagger$ & 1.61 \\
\hline Mean & $0.11^{*}$ & $0.23^{*}$ & 3.73 & 4.42 \\
\hline
\end{tabular}

* Significantly different, $P<0.025$ (paired $t$ test).

$\dagger \mathrm{CL}$ relatively ischaemic and appeared to be undergoing premature regression.

\section{Experiment 2: perfusion of microspheres into the ovaries}

As shown in Table 2, in both the ovary with and the ovary without a CL, the proportion of the dose which was retained was significantly greater for the $50 \mu \mathrm{m}$ than for the $15 \mu \mathrm{m}$ diameter microspheres $(P>0.01)$. However, while the recovery rate for the $15 \mu \mathrm{m}$ microspheres was $91.1 \pm 1.2 \%$ of that for $50 \mu \mathrm{m}$ microspheres in the ovary with a CL, it was only $53.9 \pm 8.8 \%$ of that for the $50 \mu \mathrm{m}$ microspheres in the ovary without a CL.

Table 2. Percentage of numbers of microspheres of 15 and $50 \mu \mathrm{m}$ diameter recovered in the ovaries of 5 anaesthetized ewes after perfusion of the microspheres into the ovaries

\begin{tabular}{cccccc}
\hline & \multicolumn{2}{c}{ Ovary without $C L$} & & \multicolumn{2}{c}{ Ovary with $C L$} \\
\cline { 5 - 6 } \cline { 5 - 6 } & $15 \mu \mathrm{m}$ & $50 \mu \mathrm{m}$ & & $15 \mu \mathrm{m}$ & $50 \mu \mathrm{m}$ \\
\hline & 29.0 & 66.0 & & 78.9 & 83.4 \\
& 67.0 & 85.0 & & 86.2 & 92.6 \\
& 63.5 & 90.4 & & 81.0 & 90.7 \\
& 37.4 & 84.6 & & 71.3 & 81.0 \\
& 27.9 & 85.4 & & 79.0 & 86.9 \\
\hline Mean & $45.0^{*}$ & 82.3 & & $79.3^{*}$ & 86.9 \\
\hline
\end{tabular}

* Significantly different from value for $50 \mu \mathrm{m}$ microspheres, $P<0.01$ (paired $t$ test). 


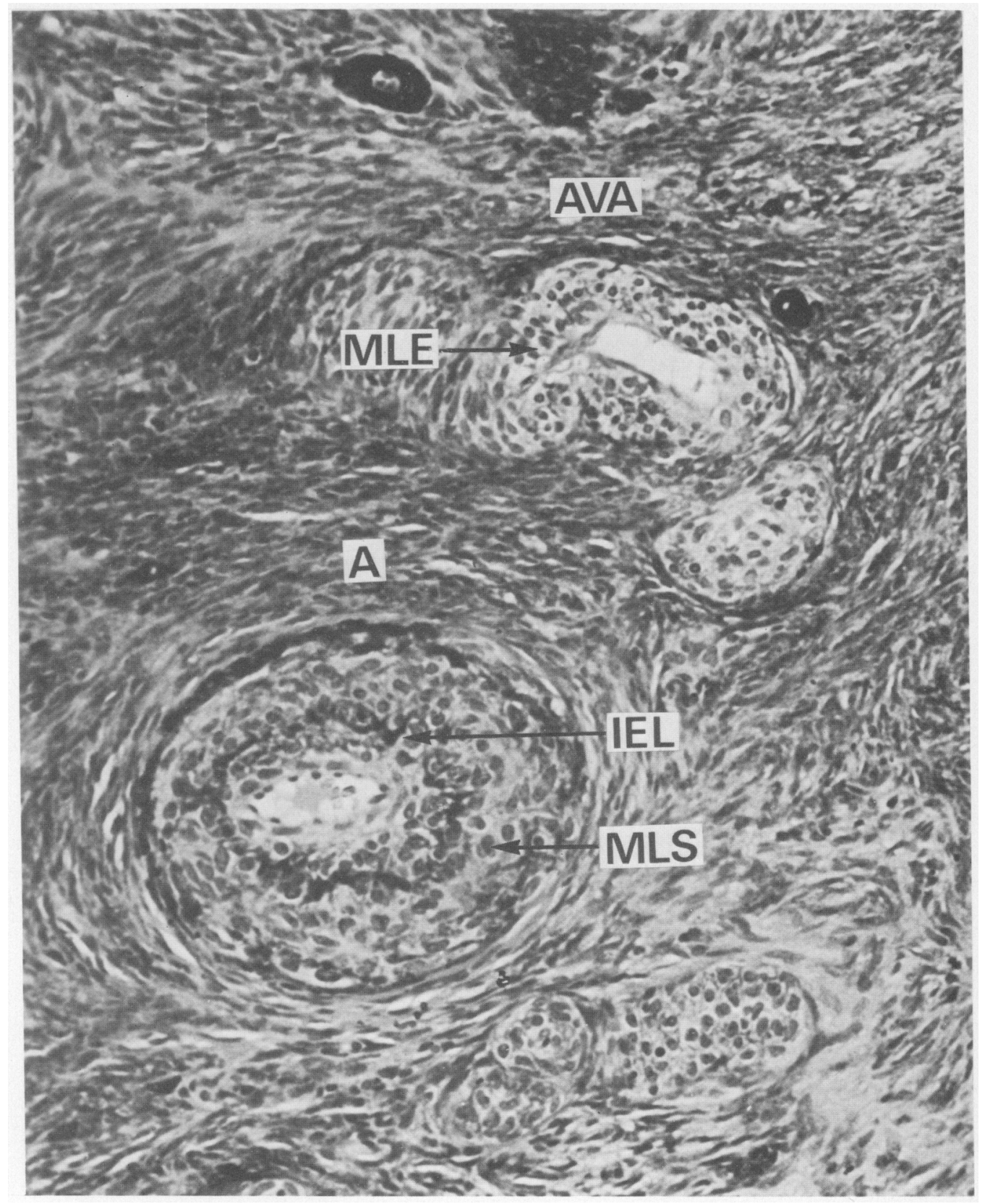

Section of a sheep ovary, stained with aldehyde-fuchsin, haematoxylin and fast green, showing an artery (A) and an arterio-venous anastomosis (AVA) in the stroma. IEL, internal elastic lamina; MLE, muscle layer composed mainly of epithelioid cells with unstained cytoplasm: MLS. muscle layer composed of smooth muscle fibres. $\times 350$. 


\section{Discussion}

The difference between the present estimates of ovarian blood flow obtained in conscious ewes by the use of 15 or $50 \mu \mathrm{m}$ diameter microsphères (Exp. 1) demonstrates that normally a proportion of the ovarian arterial supply is shunted through arterio-venous anastomoses within some region of the ovarian vascular system. The proportion of blood shunted may have been greater than presently indicated because the data in Table 2 show that some anastomoses with diameter $>50 \mu \mathrm{m}$ occur in sheep ovaries. Lee \& O'Shea (1976) injected latex into the extrinsic ovarian blood vessels in ewes and found that some anastomoses of diameter $<20 \mu \mathrm{m}$ were present in the distal part of the ovarian vascular pedicle. However, it has not yet been determined whether these vessels are functional in vivo. In the present study, vessels with histological features characteristic of arterio-venous anastomoses were found in the ovarian stroma. When microspheres were perfused into the ovary via a catheter system which ensured that the arterial blood bypassed the vasculature in the ovarian pedicle, shunting of arterial blood still occurred, as demonstrated by the recovery rate being lower for microspheres of $15 \mu \mathrm{m}$ diameter than for those of $50 \mu \mathrm{m}$ diameter. Evidently, therefore, the arterio-venous anastomoses located in the ovaries of ewes are functional.

In ovaries without a CL, the mean recovery rate for $15 \mu \mathrm{m}$ microspheres (Exp. 2) was only about half of that for $50 \mu \mathrm{m}$ microspheres, indicating that a significant proportion of the arterial flow was being diverted through anastomoses with an effective diameter of $>15$ and $<50 \mu \mathrm{m}$. In contrast, a high proportion of microspheres of both sizes was retained in the contralateral ovaries with CL.

These observations at first suggest that fewer of the anastomoses are patent in ovaries with a CL than in those without a CL. However, when a CL is present in an ovary, the blood flow to that ovary increases by several orders of magnitude (Niswender, Moore, Akbar, Nett \& Diekman, 1975; Brown, Emery \& Mattner, 1980) and practically all of the additional blood is received by the CL (Brown et al., 1974; Niswender et al., 1975) which is devoid of arterio-venous anastomoses. Therefore, if there were no change or even a small increase in the number of anastomoses patent when a CL develops, the anastomosal flow would constitute only a small fraction of the blood supply received by the ovary. The results with conscious ewes (Exp. 1) are in accord with this proposition because anastomosal flow in the ovarian vasculature was greater for ovaries with CL than for ovaries without CL.

Prostaglandin F-2 $\alpha$ induces regression of the ovine CL by a selective reduction of the luteal capillary blood flow (Thorburn \& Hales, 1972), which is not accompanied by an immediate decrease in total ovarian blood flow (McCracken, 1971). Accordingly, it seems that the arterio-venous anastomoses in the ewe ovary constitute pathways through which blood may be diverted away from the vascular beds of the CL during the early stages of luteolysis. Additionally, selective opening and closure of these vessels could permit variation in local or regional blood flow within the ovary, such as alteration in nutrient blood flow to follicles during growth or regression, to occur without change in overall blood supply to the ovary.

We thank Mr R. T. Gemmell and Mr I. D. Maddocks for histological preparation of the ovarian tissues, and Mr A. A. Fawcett and Mr S. A. Lane for technical assistance.

\section{References}

Ahrén, K., Janson, P.O. \& Selstam, G. (1974) Search for arterio-venous shunts in the rabbit ovary in situ using perfusion of microspheres. J. Reprod. Fert. 41, 133142.
Baird, D.T., Giles, M. \& Cockburn, F. (1973) The $\mathrm{PO}_{2}$ $\mathrm{PCO}_{2}, \mathrm{pH}$ and oxygen content of ovarian venous blood of sheep. J. Endocr. 57, 405-411.

Brown, B.W., Hales, J.R.S. \& Mattner, P.E. (1974)

Downloaded from Bioscientifica.com at 04/26/2023 10:58: 00AM 
Capillary blood flow in sheep ovaries, measured by iodoantipyrine and microsphere techniques. Experientia 30, 914-915.

Brown, B.W., Emery, M.J. \& Mattner, P.E. (1980) Ovarian arterial blood velocity measured with Doppler ultrasonic transducers in conscious ewes. J. Reprod. Fert. 58.295-300.

Clara, M. (1956) Die arterio-venösen Anastomosen, 2nd edn. Springer-Verlag, Wein.

Dabelow, A. (1939) Das Gefässnetz des ovars und sein Verhatten während der zyklischen Veränderungen. Verh. anat. Ges., Jena 47, 172-182.

Danesino, V. (1948) Le anastomosi artero venose dell'ovario umano. Boll. Soc. ital. Biol. Sper. 24, 1089-1091.

Fraser, I.S., Baird, D.T. \& Cockburn, F. (1973) Ovarian venous blood $\mathrm{PO}_{2}, \mathrm{PCO}_{2}$ and $\mathrm{pH}$ in women. $J$. Reprod. Fert. 33, 11-17.

Fullmer, H.M. (1959) The peracetic-orcein-Halmi stain: a stain for connective tissue. Stain Technol. 34, 81-84.

Gomori, G. (1950) Aldehyde-fuchsin: a new stain for elastic tissue. Am. J. clin. Path. 20,665-666.

Hales, J.R.S. (1974) Radioactive microsphere techniques for studies of the circulation. Clin. exp. Pharmac. Physiol. Suppl. 1, 31-46.

Lee, C.S. \& O'Shea, J.D. (1976) The extrinsic blood vessels of the ovary of the sheep. J. Morph. 148, 287-303.

Mattner, P.E. \& Thorburn, G.D. (1969) Ovarian blood flow in sheep during the oestrous cycle. J. Reprod. Fert. 19, 547-549.

Mattner, P.E., Hales, J.R.S. \& Brown, B.W. (1972) Blood flow in the ovary in sheep. Proc. Aust. physiol. pharmac. Soc. 3, 144, Abstr.

McCracken, J.A. (1971) Prostaglandin F2 $\alpha$ and corpus luteum regression. Ann. N.Y. Acad. Sci. 180, $456-469$.

Molyneux, G.S. (1965) Observations on the structure, distribution, and significance of arterio-venous anastomoses in sheep skin. In Biology of the Skin and Hair Growth, pp. 591-602. Eds A. G. Lyne \& B. F. Short. Angus and Robertson, Sydney.

Niswender, G.D., Moore, R.T., Akbar, A.M., Nett, T.M. \& Diekman, M.A. (1975) Flow of blood to the ovaries of ewes throughout the estrous cycle. Biol. Reprod. 13, 381-388.

Setchell, B.P. \& Linzell, J.L. (1974) Soluble indicator techniques for tissue blood flow measurement using ${ }^{86} \mathrm{Rb}$-rubidium chloride, urea, antipyrine (phenazone) derivatives or ${ }^{3} \mathrm{H}$-water. Clin. exp. Pharmac. Physiol. Suppl. 1, 15-29.

Thorburn, G.D. \& Hales, J.R.S. (1972) Selective reduction in blood flow to the ovine corpus luteum after infusion of prostaglandin $\mathrm{F} 2 \alpha$ into a uterine vein. Proc. Aust. physiol. pharmac. Soc. 3, 145, Abstr.

Watzka, M. (1936) Über Gefaessperren and arteriovenöse Anastomosen. Z. mikrosk.-anat. Forsch. 39, 521-544.

Received 20 October 1980 